PETR ŠIMÁČEK

Masaryk University, Czech Republic

ZDENĚK SZCZYRBA

Palacký University, Czech Republic

\title{
Changes of the business environment in the sector of construction for residential purposes - a case study of the Czech Republic
}

The transformation of Czech economy after 1989 brought many changes. Gradually, new organizational, institutional and legal frameworks were shaped for the operation of a market mechanism. Similar to a number of other branches, the construction industry transformed significantly (Myant \& Drahokoupil 2010; Spěváček et al. 2002; Tsenkova 2009). The first half of the 1990s was marked by restructuring, privatization and subsequent internationalization, which have brought (among other things) many construction innovations. Part of these processes was also the change of housing forms, characterized by gradual departure from state directives in residential construction, to institutional support of entrepreneurship, to highly integrated residential development. This last form of construction business is present only in the largest Czech cities or in selected mountain resorts and contributes significantly to the overall volume of housing construction in the country. Currently thousands of smaller domestic companies are operating in the construction sector of industry, but their position continues to decline. This is due to large multinational companies' entering the Czech market, primarily as a result of privatization of the sector. Construction in the Czech Republic is characterized by a high degree of concentration.

TRANSFORMATION OF THE CONSTRUCTION INDUSTRY - CAUSAL RELATIONS

The arrangement of the centrally planned economy had a major impact on motivation and behavior of economic entities, whose sole aim was the fulfillment of the plan drawn up by the center. Profit was not observed as a mandatory (and the most important) indicator. In Czechoslovakia (as in Poland and other socialist countries), this system proved to be 
completely dysfunctional in practice. Motivation in the form of fulfillment of the plan was inadequate and ultimately led to technological backwardness, loss of dynamics in increasing the efficiency and thereby loss of competitiveness with the outside world (Jarosz 2010).

A typical feature of the system of central planning was the monopolization of the economy with emphasis on industrialization. According to Ř́nová (2009), the main aim of monopolization was facilitating management of individual subjects. The problem of the economic center was the inability to recognize and estimate demand of the people. In addition, companies were not able to export and thus gain currency to import advanced technologies from western countries.

The situation in the construction industry is no different from the rest of the economy. The principles of the centrally planned economy were evident in the construction industry in the considerable concentration of production. The central authority for the sector was the Ministry of Construction (in Czech Ministerstvo stavebnictvi), which used to establish enterprises by construction branches. For example, for housing the Pozemni stavby was established, for transportation - the Stavby silnic a železnic, for the construction of the underground - Metrostav, etc.

An illustration of malfunctioning of the construction industry was, for example, housing construction. The housing market did not exist, and dwellings were not sold but were assigned (Jarosz 2010; Tsenkova 2009). Housing construction was realized mostly in the form of prefabricated construction, regardless of any utility properties of flats, their functionality, architectural design, individual needs of people or energy efficiency. The cost of dwellings was set regardless to the labor productivity and the real cost of construction or maintenance. Individual construction of houses was minimal and was carried out by self-help without the

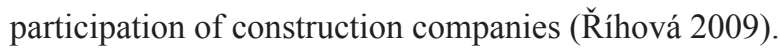

The early 1990s brought changes in the political regime in the Central and Eastern Europe, which triggered the process of transforming planned controlled economies to market economies. The transformation process in Czechoslovakia was oriented towards three basic objectives: market liberalization, economic stabilization and privatization of the state property. Regarding the role of government in the restructuring process in the beginning, it was to contribute to the change in the relations between the national economy sectors, to support toward structural changes that allow the transition to the market mechanism, and to keep the economy running. The new government focused mainly on deconcentration and subsequent demonopolization of enterprises. To meet the objectives defined, privatization of state property was used (Myant \& Drahokoupil 2010; Ř́hová 2009; Tsenkova 2009).

\section{Privatization AND INTERNATIONALIZATION}

\section{IN THE CONSTRUCTION INDUSTRY}

The basis of restructuring became privatization, which in the Czech conditions began in late 1990 and 1991; its primary goal was to create a functioning market. For this purpose, a specialized Ministry was established (Ministerstvo pro správu národního majetku a jeho privatizaci). This Ministry had to decide in matters of transfer from state property to private 
ownership. Government policy of this period was to privatize mostly flat and fast (Spěváček et al. 2002). The privatization was carried out along two paths. The first one was the so-called Small privatization, in which small economic units were sold in public auctions, where the primary objective was to revive the sector of small businesses. The second path was the Large privatization, which concerned medium and large enterprises (especially large industrial plants and banks). In this path of privatization several methods were used, of which the most famous is so-called Voucher privatization, which is largely related to the construction industry.

Tab. 1. Percentage share of enterprises with 20 and more employees according to the form of ownership in the Czech Republic (resp. in Czechoslovakia) in the period 1991-2000

\begin{tabular}{|l|c|c|c|c|c|}
\hline form of ownership & $\mathbf{1 9 9 1}$ & $\mathbf{1 9 9 2} * \boldsymbol{1}$ & $\mathbf{1 9 9 3} \boldsymbol{*}$ & $\mathbf{1 9 9 4} \boldsymbol{*}$ & $\mathbf{1 9 9 5} \boldsymbol{* *}$ \\
\hline private & 4 & 41 & 71 & 85 & 88 \\
\hline public & 91 & 44 & 19 & 7 & 3 \\
\hline other & 5 & 15 & 10 & 8 & 9 \\
\hline & $\mathbf{1 9 9 6}$ & $\mathbf{1 9 9 7}$ & $\mathbf{1 9 9 8}$ & $\mathbf{1 9 9 9}$ & $\mathbf{2 0 0 0}$ \\
\hline private & 89 & 91 & 92 & 93 & 98 \\
\hline public & 2 & 1 & 1 & 1 & 0 \\
\hline other & 9 & 8 & 7 & 6 & 2 \\
\hline
\end{tabular}

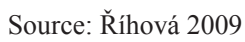

* Enterprises with 100 and more employees

** Enterprises with 25 and more employees

As it is shown in Table 1, privatization of the construction industry brought new ownership structure. Although the data for each of the years are not wholly comparable, their interpretive value may be considered relevant in view of the industry's nature in the early 1990s, when big-sized enterprises prevailed over small-sized ones. While 1991 still saw a considerable dominance of state enterprises, in 1992 the state vs. private sector ownership structure was practically balanced. During 1993, the private enterprises prevailed and they were continually increasing their share until the year 2000, from which this structure has basically remained unchanged.

Transformation of the Czech economy was also reflected in the size structure of enterprises. As evidenced by data in Table 2, there was a significant increase in the number of small companies and decrease in the number of major companies. Atomization of the construction industry considerably contributed to the restructuring of the sector and thereby started greater efficiency and competitiveness of construction enterprises. A fundamental change was observed especially in the smallest category of firms: between 1992 and 2010 the share of companies in the category of 20-99 employees doubled in the total number of firms. 
Tab. 2. Number of enterprises according to number of employees in the construction sector in the Czech Republic (or Czechoslovakia) in 1992-2010

\begin{tabular}{|c|c|c|c|c|c|c|c|c|c|c|}
\hline \multirow{2}{*}{$\begin{array}{c}\text { number } \\
\text { of employees }\end{array}$} & \multicolumn{2}{|c|}{1992} & \multicolumn{2}{|c|}{1995} & \multicolumn{2}{|c|}{2000} & \multicolumn{2}{|c|}{2005} & \multicolumn{2}{|c|}{2010} \\
\hline & abs. & $\%$ & abs. & $\%$ & abs. & $\%$ & abs. & $\%$ & abs. & $\%$ \\
\hline $20-99$ & 339 & 43,0 & 1264 & 70,9 & 1896 & 85,6 & 2208 & 88,4 & 1879 & 87,7 \\
\hline $100-299$ & 241 & 30,6 & 378 & 21,2 & 256 & 11,6 & 226 & 9,0 & 206 & 9,6 \\
\hline $300-499$ & 104 & 13,2 & 81 & 4,5 & 35 & 1,6 & 38 & 1,5 & 29 & 1,4 \\
\hline $500-999$ & 83 & 10,5 & 45 & 2,5 & 19 & 0,9 & 16 & 0,6 & 19 & 0,9 \\
\hline 1000 and more & 21 & 2,7 & 16 & 0,9 & 10 & 0,5 & 10 & 0,4 & 10 & 0,5 \\
\hline total & 788 & 100,0 & 1784 & 100,0 & 2216 & 100,0 & 2498 & 100,0 & 2143 & 100,0 \\
\hline
\end{tabular}

Source: Stavebnictví České republiky, 2011; own processing

Note: in the years 1992 and 1995 the first category is 25-99 employees

According to the Czech Statistical Office (2011b), long-term employment in the construction industry in the Czech Republic oscillates around 450 thousand workers (484 thousand in 2010), while the share of total employment is around $9 \%(9,6 \%$ in 2010$)$. The construction industry accounts for about $6 \%$ (6,4\% in 2010) of the gross domestic product.

While in the first years of the transformation process the basis of changes (not just in construction sector) was atomization of large enterprises and the resulting dynamic development of small firms, in the second half of the 1990s the construction industry was "hit" by a wave of internationalization. The gradual integration of the Czech Republic into the world economy meant the inflow of foreign capital (initially in the form of investments to privatized companies). Among the largest and best known foreign construction companies operating in the Czech Republic is - since 1992 - the French Eurovia CS (VINCI Group member - the largest construction group in the world), which now owns $100 \%$ of the original Czechoslovak state enterprise Stavby silnic a železnic. On the same principle, the Swedish company Skanska entered the Czech market, taking over the original Czechoslovak state enterprise Inženýrské a průmyslové stavby. As other examples of large foreign construction companies that decided to expand to the Czech Republic and use one of the state-owned companies we can name the Austrian Strabag or the German Hochtief.

Foreign companies brought with them new know-how, the essence of which are innovations in the fields of technology, management systems, new products or improved construction materials. But as stated in Frková (2007, p. 72), in the terms of innovations, the Czech construction industry is facing a necessary task, which is significant reduction of the negative impacts of construction on the environment. In particular, it is reduction of energy consumption in both the construction and operation of new buildings. Nowadays the energy-efficient buildings are no exception, but their implementation into common construction practice is still non-existent.

Along with the internationalization of the construction sector, activities of development companies began. The activity of developers is the creation of the concept of real estates' use for financial gain (either for sale or lease) and the subsequent realization of this plan. The most 
common types of the developer projects are residential and other non-residential commercial constructions (offices, warehouses, etc.). It is very often that a residential development company is founded by its parent company (for example Skanska - Skanska Reality). In such cases, the parent company strives to maximize the number of its contracts and thereby increase profits. The largest developer companies operating in the Czech Republic are Luxembourg Orco Property Group and ECM Real Estate Investments, which entered the Czech market already in the 1990s. Along with the Skanska Reality, the mentioned companies have almost exclusively residential projects in their portfolio. The main region of their activity is the capital city of Prague and its hinterland.

\section{Housing construction in the Czech Republic}

In the past transformation period the residential construction in the Czech Republic experienced significant changes, as shown in Figure 1, presenting development of the intensity of housing construction over the years 1989-2010. The first half of the 1990s meant a significant downturn for residential construction. During this period large housing construction projects started in so called complex housing construction were still running, which was the bearing element of housing construction in the socialist Czechoslovakia, and other residential construction was carried out in the least degree. The volume of completed dwellings began to increase since 1996, when the mortgage and building societies markets started to develop. Since this year, the trend in the number of dwellings completed was still growing until 2007. It's worth noting that in 2007 the same intensity of housing construction was reached as in the early transition period, and that never in the past twenty years has such intensity of housing construction been reached as at the end of socialism. Development after 2007 was greatly affected by the economic crisis, which inhibited the activity of both the largest construction firms and the largest developers in the country. As a result, some companies (which had considerable volume of unoccupied and under-construction apartments) suffered from the financial difficulties or even failures (for example ECM Real Estate Investments).

There are two major markets in the spatial distribution of new housing construction in the Czech Republic. The so-called primary market affects the Prague metropolitan region and concentrates almost $40 \%$ of dwellings completed within the Czech Republic for the construction period 1997-2010. Other administrative regions of the Czech Republic are called the secondary market. With the exception of some large Czech cities, it is the market which is dominated by regional builders and developers.

The more specific picture of regional differences in primary and secondary housing construction markets in the Czech Republic is offered in Figure 2. It shows the intensity of housing construction and its development of extremes, by administrative regions. Behind the high values of the Středočeský region is the new residential construction, which is taking place mainly in the form of suburbanization in the hinterland of the City of Prague (Němec 2011; Ouředníček \& Posová 2006; Sýkora \& Posová 2007). In contrast, the intensity of housing construction in Karlovarský and Ústecký region are long-term among the lowest in the Czech Republic. The factor contributing to very low values of the intensity of housing 
construction in the Ústecký region is the generally known „trouble” of the territory, which can be characterized by high unemployment rate, frequent occurrence of socio-pathological phenomena, low inflow of foreign investment, low innovation potential, etc. (Spěváček et al. 2002). The Ústecký region is also characterized by a significant surplus of housing construction from the socialist period, and new construction, due to weak economic indicators and lower living standards of its inhabitants, is below average in comparison with other regions of the Czech Republic.

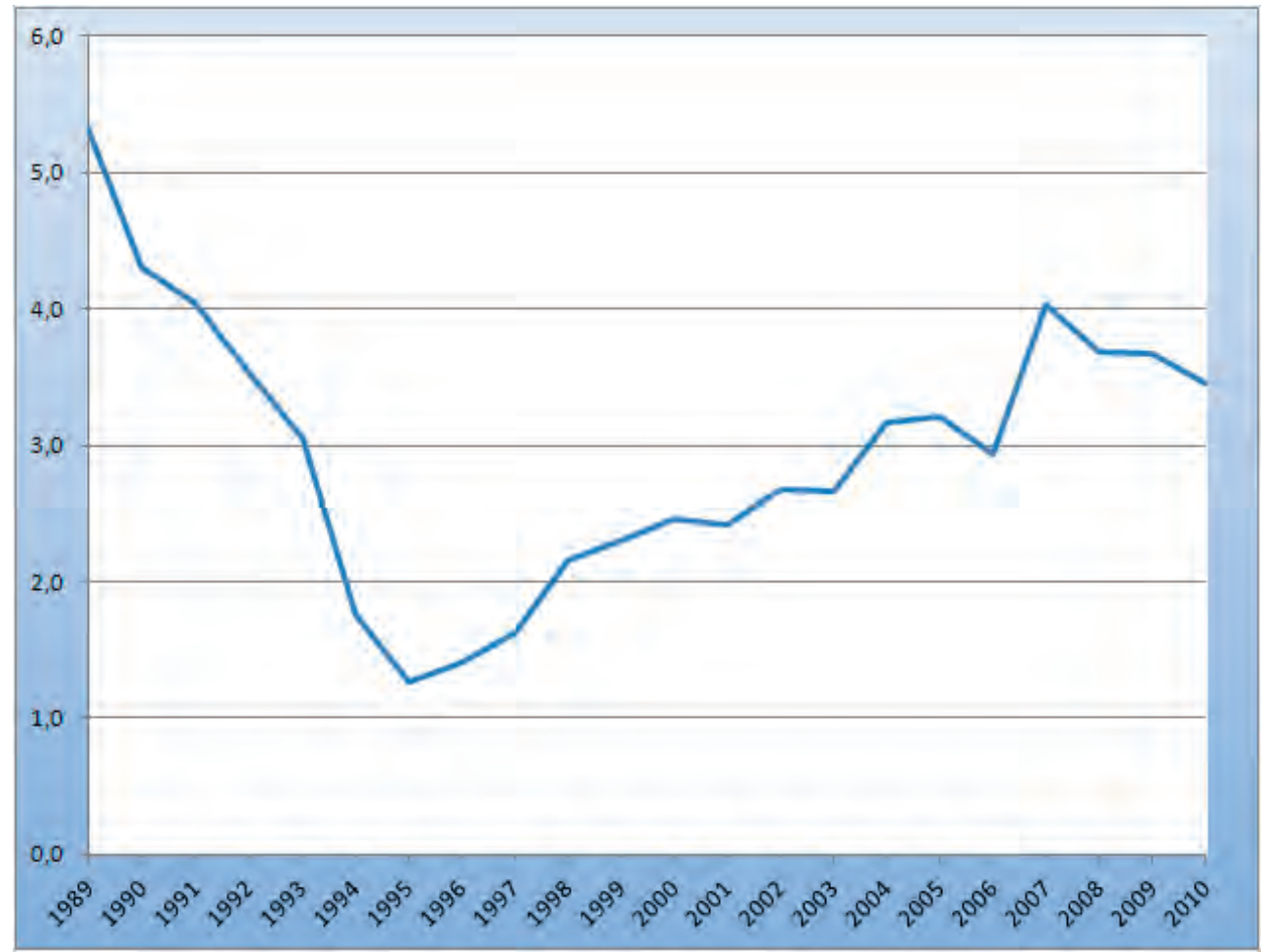

Fig. 1. Intensity of housing construction (dwellings completed per 1000 inhabitants) in the period 1989-2010 in the Czech Republic

Source: Czech Statistical Office, 2011a, 2011c; own processing

It is interesting that at the end of the economic prosperity (2007), the difference between the maximum and the minimum value of the intensity of housing construction in regions was approximately eight times greater compared to the initial state (1997).

As already mentioned, the Czech construction industry is undergoing significant technological changes. They are caused by the arrival of foreign construction companies on the Czech market, applying modern building techniques, as well as construction systems suppliers of various kinds (for example mortar mixtures or insulation), often from abroad. In the current phase of internationalization far greater use of new technologies can be seen in the 
construction industry than a few years earlier. For example, the character of construction of flats by bearing structures changed significantly. It became more frequent in the residential construction to apply other structures than masonry, as the proportion of wood in housing construction has increased from $1,5 \%$ in 1997 to $4,1 \%$ in 2010 . Another ,revolution” in the Czech construction industry is living in low-energy homes. This type of housing construction is becoming more and more popular in the Czech Republic. It is even evidenced that this segment of the residential construction was not affected by the last economic crisis and the number of flats built in this way is growing. The low-energy trend is also strongly supported by the European Union. The EU recently approved a directive according to which only energy efficient houses should be build from 2020 on. Since 2009, the ,green savings” program (in Czech Zelená úsporám) has been carried out in the Czech Republic. It is a program of subsidies to extensive technological revitalization of the housing stock on the basis of funds obtained by selling emission credits to Japanese companies. At the end of 2011 the program has already covered revitalization of housing stock for more than 10 billion crowns.

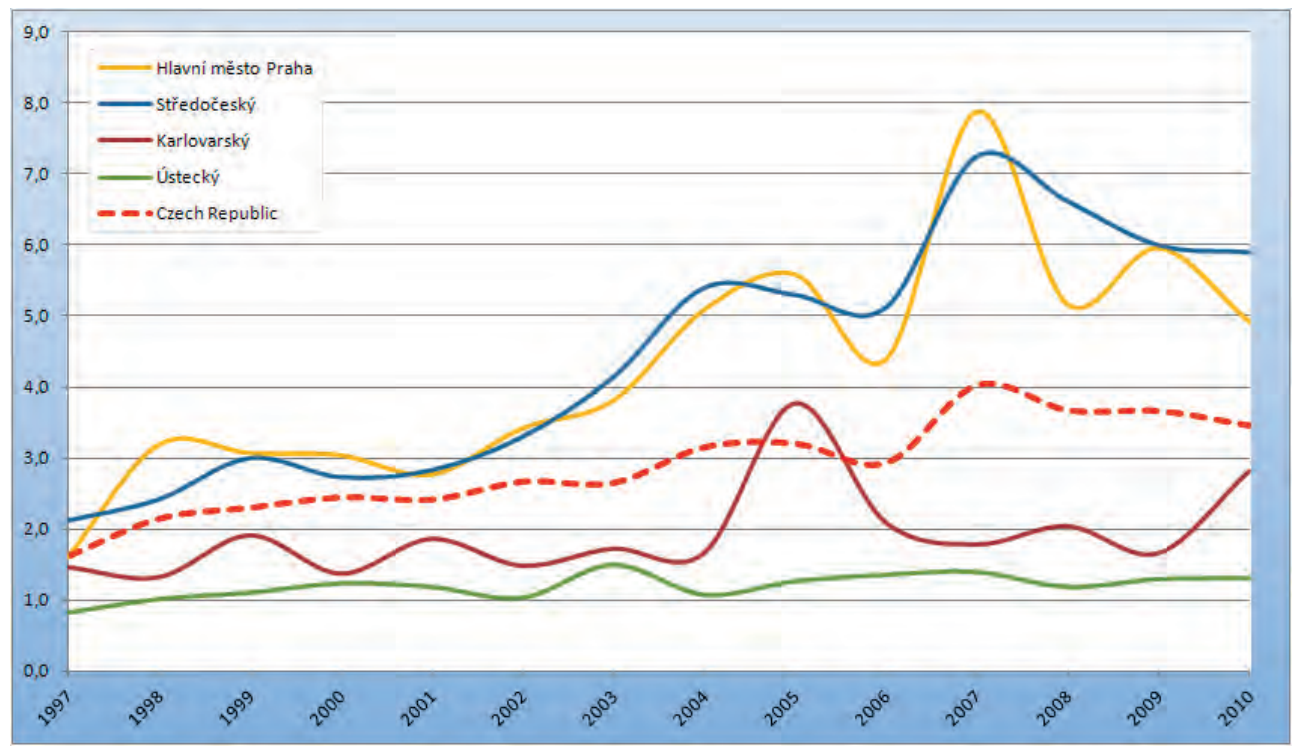

Fig. 2. Intensity of housing construction (dwellings completed per 1000 inhabitants) in the period 1997-2010 according to administrative regions of the Czech Republic (extreme examples) 


\section{CONCLUSions}

The business environment in the Czech construction industry experienced significant changes during the transformation period. In the beginning of the transformation, the sector reported a high degree of monopolization, because there were very few large state-controlled enterprises to execute virtually all of construction in the country. However, during the transition period the sector experienced radical transformation, especially in its size and ownership structure. In the early 1990s, in the first phase, which can be described as atomizing, there was a boom for small and medium enterprises, which are still the fundament of the entire branch of industry. The market of large construction companies (that appeared either as a privatization project, or as the result of expansion of foreign companies) was developing. An integral part of the construction industry in the Czech Republic is construction development, dominated by foreign companies. They focus mainly on the primary market (especially the capital city of Prague and its hinterland), while the secondary market is still the domain of local construction companies of various sizes. The activities of both types of companies were significantly slowed down by the effects of the economic crisis, exemplified by the reduction of housing construction after 2007 (see Figure 1).

If we follow the development of business environment in the construction industry in the Czech Republic during the economic crisis, then we can observe that this crisis hit big foreign construction companies as well as smaller domestic companies. But the truth is that despite some failures of large companies (for example developer ECM Real Estates Investments) there were far more bankrupt smaller companies (see Table 2). Basing on this fact, deepening of concentration tendencies in the sector could be expected, but this idea is refuted by the statistical indicators. Concentration of the construction industry between 2007 and 2010 even slightly decreased (measured by the share of the largest companies on revenues from sales of own goods and services in the construction sector in the mentioned years). While in 2007 the TOP 5 companies reached the share of $38,4 \%$ and the TOP 10 - the share of $47,4 \%$, in 2010 the group of TOP 5 companies showed the share of $37,3 \%$ and the TOP 10 - the share of $45,4 \%$. In the near future, however, significant strengthening of the position of large companies can be expected, which will lead to re-increase of the concentration in the construction industry.

\section{Changes of the business environment in the sector of construction for residential purposes - a case study of the Czech Republic}

The transformation of Czech economy after 1989 brought many substantial changes. Gradually, new organizational, institutional and legal frameworks were shaped for the operation of a market mechanism. Similar to a number of other branches, the construction industry transformed significantly. The first half of the 1990 was marked by the restructuring, privatization and subsequent internationalization, which continued in the second half of the decade. Opening of the market towards the west, and the internationalization have brought many innovations. They can be seen for example in the application of new technologies or the implementation of modern building materials. A typical example of these innovations is the boom in construction of low-energy houses. 
The paper also deals with the gradual change in the residential construction, characterized by the gradual departure from state directives in residential construction, to institutional support of entrepreneurship, to highly integrated residential development.

This paper was elaborated under the project GA AV ČR IAA301670901 „Časoprostorová organizace denních urbánních systémů: analýza a hodnocení vybraných procesư" "and project IGA UP PrF_2011_006 „Krajina jako geosystém: změny v časové a prostorové struktuře a jejich hlavní mechanismy“ funded by the Faculty of Science, Palacký University in Olomouc, Czech Republic.

\section{References}

ČSÚ, 2011a, Česká republika od roku 1989 v čislech: Tab. 11.01 Bytová výstavba v České republice [online], Czech Statistical Office, available at: http://www.czso.cz/cz/cr_1989_ts/1101.pdf

ČSÚ, 2011 b, Databáze RNÚ-Zaměstnanost celkem (osoby): Tab. M000131a [online], Czech Statistical Office, available at: http://apl.czso.cz/pll/rocenka/rocenkavyber.makroek_pracov

ČSÚ, 2011c, Statistická ročenka České republiky 2011 - 29. VYBRANÉ UKAZATELE OBLASTÍ A KRAJU: Tab. 29-2. Vybrané ukazatele krajů (NUTS 3) v roce 2010 [online], Czech Statistical Office, available at: http://www.czso.cz/csu/2011 edicniplan.nsf/t/2E00396DBF/\$File/0001112902. xls

Frková J., 2007, Analýza cyklů investični výstavby vyvolaných inovacemi ve vztahu k rozvoji bydlení a makroekonomické souvislosti, [in:] M. Ferko (ed.), Výzkum proměn bydlení v České republice, VŠB-Technická univerzita Ostrava, Ostrava, p. 67-81.

Jarosz D., 2010, MIESZKANIE się należy... Studium z peerelowskich praktyk społecznych, Warsaw, p. 388.

LABORSTA Internet: CZECH REPUBLIC and CZECHOSLOVAKIA (Statistics by country), 2011, Total employment, by economic activity [online], International Labour Organization, available at http://laborsta.ilo.org/STP/guest

Myant M., Drahokoupil J., 2010, TRANSITION ECONOMIES: Political Economy in Russia, Eastern Europe and Central Asia, Wiley, p. 391.

Němec M., 2011, Bytová výstavba na území pražského metropolitního regionu v obdobi 2005-2010 a odhad jejího vývoje do roku 2016, Urbanismus a územní rozvoj, Vol. XIV, No 5, p. 33-44.

Oư̌edníček M., Posová D., 2006, Suburbánni bydleni v Pražském městském regionu: etapy vývoje a prostorové rozmistení, [in:] M. Ouřednícek (ed.) Sociálni geografie Pražského městského region, Univerzita Karlova v Praze, Prague, p. 96-113.

Ŕíhová B., 2009, Komparace procesu restrukturalizace stavebnictvi ČR a vybrané tranzitivni ekonomiky (Slovensko), diplomová práce, Masarykova Univerzita, Brno, p. 77.

Spěváček V. et al., 2002, Transformace české ekonomiky politické, ekonomické a sociální aspekty, Prague, p. 525.

Stavebnictví České republiky, 2011, Organizační struktura stavebnictví [online], ÚRS Praha a.s., Prague, available at: http://www.mpostav.cz/orgstr.htm

Sýkora L., Posová D., 2007, Specifika suburbanizace v postsocialistickém kontextu: nová bytová výstavba v metropolitni oblasti Prahy 1997-2005, Geografie-Sborník ČGS, Vol. 112, No 3, p. 334-356.

Tsenkova S., 2009, Housing Policy Reforms in Post Socialist Europe. Lost in Transition, Heidelberg, p. 262 
Mgr. Petr Šimáček

Masaryk University, Brno, Czech Republic

Faculty of Science

Department of Geography

e-mail:simacek@mail.muni.cz

Doc. RNDr. Zdeněk Szczyrba, Ph.D.

Palacký University, Olomouc, Czech Republic

Faculty of Science

Department of Geography

e-mail: zdenek.szczyrba@upol.cz 